\title{
Biology and Management of Florida Betony (Stachys floridana) in Ornamental Plants in Landscape Planting Beds ${ }^{1}$
}

\section{Thomas Smith and Chris Marble ${ }^{2}$}

\section{Introduction}

Florida betony (Stachys floridana) is a perennial weed mostly found in Florida landscape planting beds, gardens, turfgrass, and agricultural production systems. This article is written for green industry professionals and others to aid in the identification and management of Florida betony in and around ornamental plants in landscape planting beds.

\section{Species Description}

\section{Class}

Dicotyledon

\section{Family}

Lamiaceae-mint family

\section{Other Common Names}

Florida betony, Florida hedgenettle, and rattlesnake weed. This species is also commonly referred to as wild artichoke, even though Florida betony and wild artichoke (Cynara cardunculus) are not related.

\section{Life Span}

Perennial cool-season herb

\section{Habitat}

Florida betony is a common weed in agricultural fields, landscape planting beds, lawns, gardens, and other disturbed areas. In landscapes, Florida betony is frequently found growing in turfgrass or in mulched planting beds. It is not typically an issue in container nurseries but can be found growing in containers when soil is recycled or when field soil is used as part of the growing mix, and it may also grow through weed mats or in noncrop areas around the nursery. This plant tolerates a wide range of environmental conditions (sun or shade, wet or dry soils, etc.), making it adaptable to many different areas in the landscape (Czarnota and Murphy 2012).

\section{Distribution}

Florida betony grows throughout the southeastern United States, from Florida north to Virginia, Texas, and California (USDA, NRCS 2020). Florida betony is believed to be native to Florida and other southeastern US states. The true origin

1. This document is ENH1333, one of a series of the Environmental Horticulture Department, UF/IFAS Extension. Original publication date December 2020. Visit the EDIS website at https://edis.ifas.ufl.edu for the currently supported version of this publication.

2. Thomas Smith, graduate research assistant, Environmental Horticulture Department, UF/IFAS Extension; and Chris Marble, assistant professor, Environmental Horticulture Department, UF/IFAS Mid-Florida Research and Education Center; UF/IFAS Extension, Gainesville, FL 32611.

The use of trade names in this publication is solely for the purpose of providing specific information. UF/IFAS does not guarantee or warranty the products named, and references to them in this publication do not signify our approval to the exclusion of other products of suitable composition. Use pesticides safely. Read and follow directions on the manufacturer's label.

The Institute of Food and Agricultural Sciences (IFAS) is an Equal Opportunity Institution authorized to provide research, educational information and other services

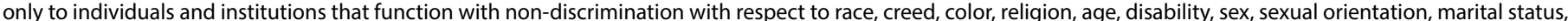
national origin, political opinions or affiliations. For more information on obtaining other UF/IFAS Extension publications, contact your county's UF/IFAS Extension office. U.S. Department of Agriculture, UF/IFAS Extension Service, University of Florida, IFAS, Florida A \& M University Cooperative Extension Program, and Boards of County Commissioners Cooperating. Nick T. Place, dean for UF/IFAS Extension. 
of this species is debated among authors because there is not $100 \%$ certainty that the species was endemic to Florida before 1940 (Unruh et al. 2016).

\section{Growth Habit}

Florida betony is an erect (upright) and densely growing herbaceous perennial plant. Stems are square and grow up to 24 inches in height (Figure 1).

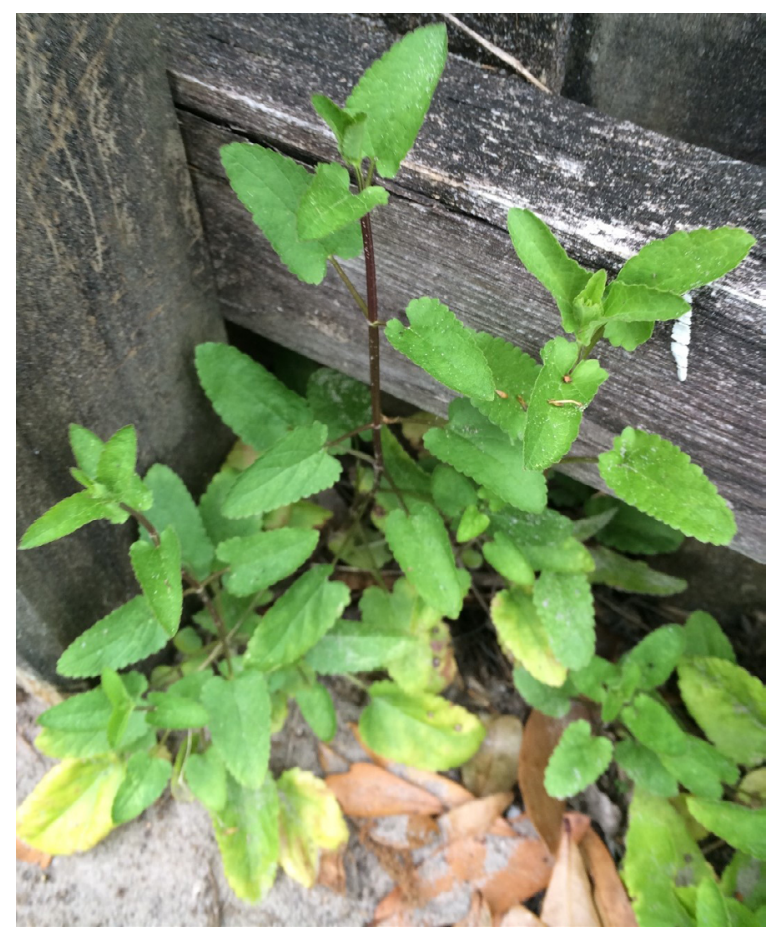

Figure 1. Florida betony growth habit.

Credits: Chris Marble, UF/IFAS

\section{Seedling}

Little is currently known about the germination of Florida betony from seed. Seed germination is likely low, with previous studies reporting germination rates of less than $20 \%$ (Stamps 1992). When first emerging from the soil, seedlings or small plants from rhizomes are similar in appearance to mature plants but with smaller leaves. Seedlings also typically have whitish to light-green stems, while mature plants may have purplish stems.

\section{Shoot}

Typical of plants in the Lamiaceae (mint) family, Florida betony has stems that are square (4-sided) and pubescent (hairy). Leaves are oppositely arranged, up to 2 inches long, and lance-shaped with a toothed (serrated) margin.

\section{Roots}

Florida betony produces rhizomes and pale-white segmented tubers that look similar to a rattlesnake's tail. Both tubers and rhizomes are free branching and break easily
(Stamps 1992). Once established, Florida betony is difficult to remove by hand because the tubers and rhizomes break easily and small root fragments can regrow (Czarnota 2012).

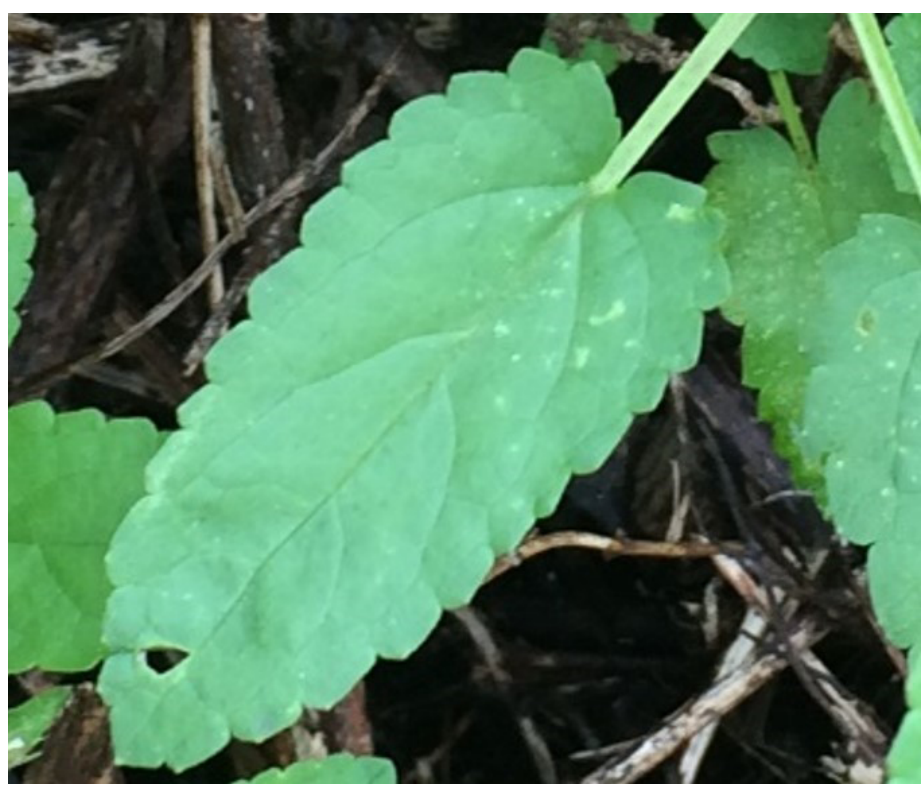

Figure 2. Florida betony leaves. Note the toothed (serrated) leaf margins.

Credits: Chris Marble, UF/IFAS

\section{Inflorescence}

Flowers emerge in clusters of 3 to 6 from the upper leaf axil. The petals are fused and have 2 lips (bilabiate), which are pink to white with purple spots (Unruh et al. 2016).

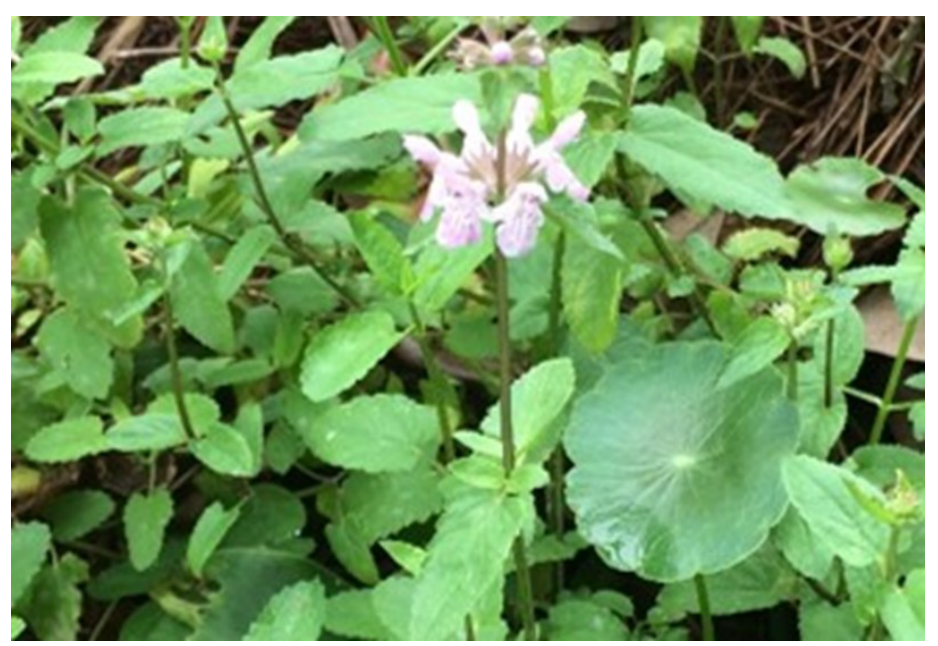

Figure 3. Florida betony inflorescence.

Credits: Chris Marble, UF/IFAS

\section{Fruit and Seeds}

Fruits are composed of 4 nutlets with single-seeded parts that split at maturity (schizocarp). They are less than an inch long with seeds a millimeter long (Unruh et al. 2016). 


\section{Similar Species}

The mint family (Lamiaceae) is a large family of aromatic herbs characterized by square stems and opposite leaves. The genus Stachys is one of the largest genera within the family, with around 450 species. In Florida, there are three other species within the genus, including S. arvensis (staggerweed), S. crenata (mouse's ear), and S. lythroides (hyssop-leaf hedgenettle) (Wunderlin 2020). Florida betony can be easily distinguished from the other species by its unique tubers that resemble a rattlesnake tail (Figure 4); related species do not produce tubers (Czarnota 2012). Staggerweed, mouse ear, and hyssop-leaf also all have shorter internode lengths compared to Florida betony (Datiles and Acevedo-Rodriguez 2019). Additionally, unlike Florida betony, staggerweed has a sprawling growth habit.

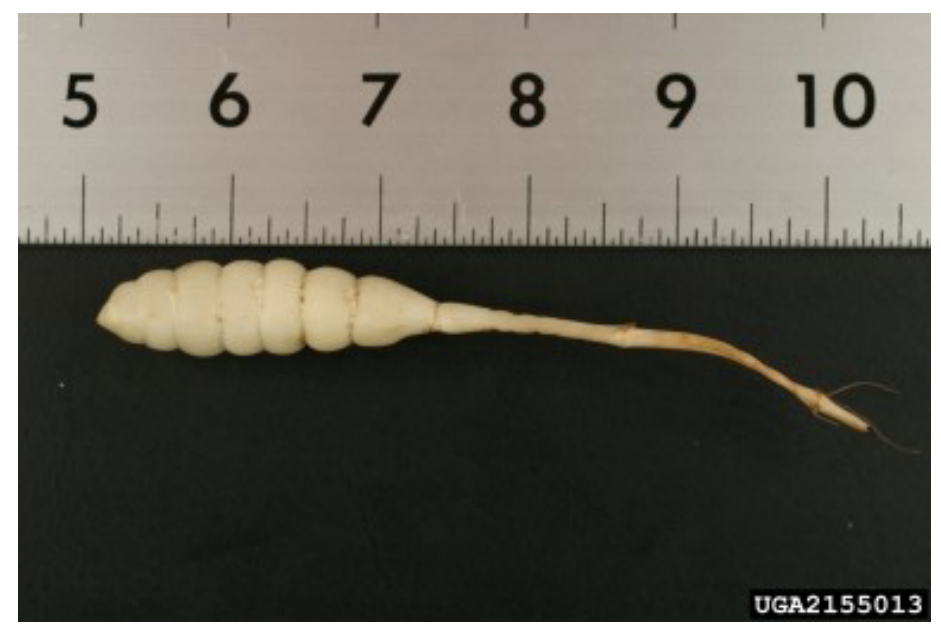

Figure 4. Florida betony tubers.

Credits: John D. Byrd, Mississippi State University, Bugwood.org

\section{Plant Biology}

Florida betony is a troublesome weed in landscapes due to its large tubers and its ability to spread via rhizomes (Figure 5). In Florida, it begins to emerge in mid- to late fall and produces segmented tubers during the spring before going dormant in the summer. Summer heat can induce dormancy after flowering, usually occurring in early to late spring (Burgess and Williamson 2019). Because Florida betony primarily spreads through asexual means (tubers and rhizomes), it can continue to spread even when it is not producing flowers (Figure 6). Reproduction by seed may also be a mechanism of dispersal, but little is known about seed germination for this species, and more research is needed (Burgess and Williamson 2019).

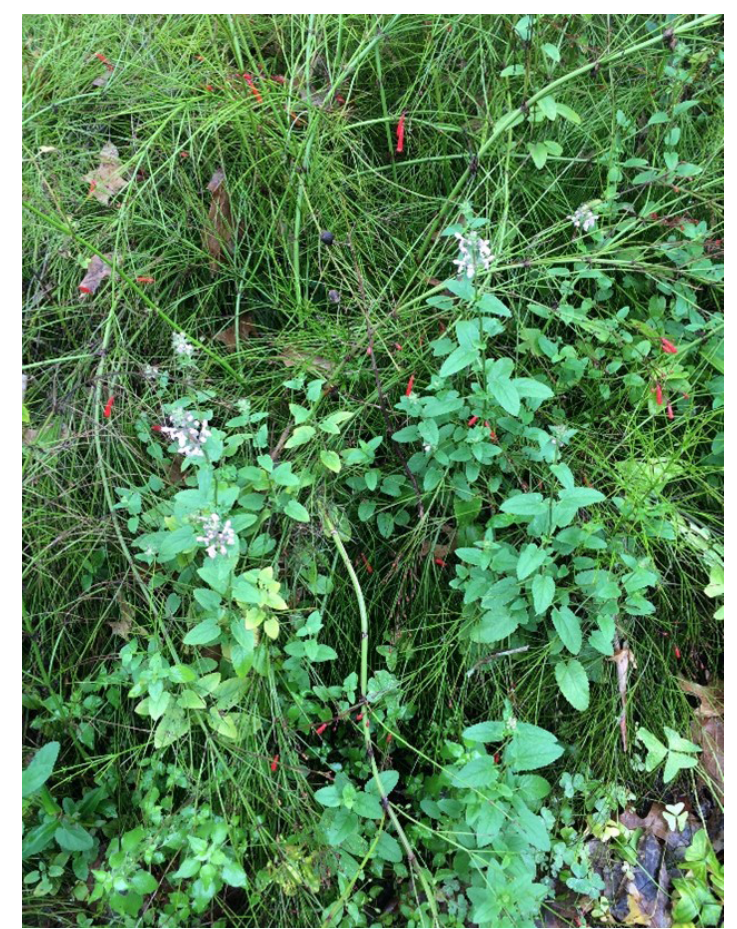

Figure 5. A Florida betony infestation in a landscape planting bed. Credits: Chris Marble, UF/IFAS

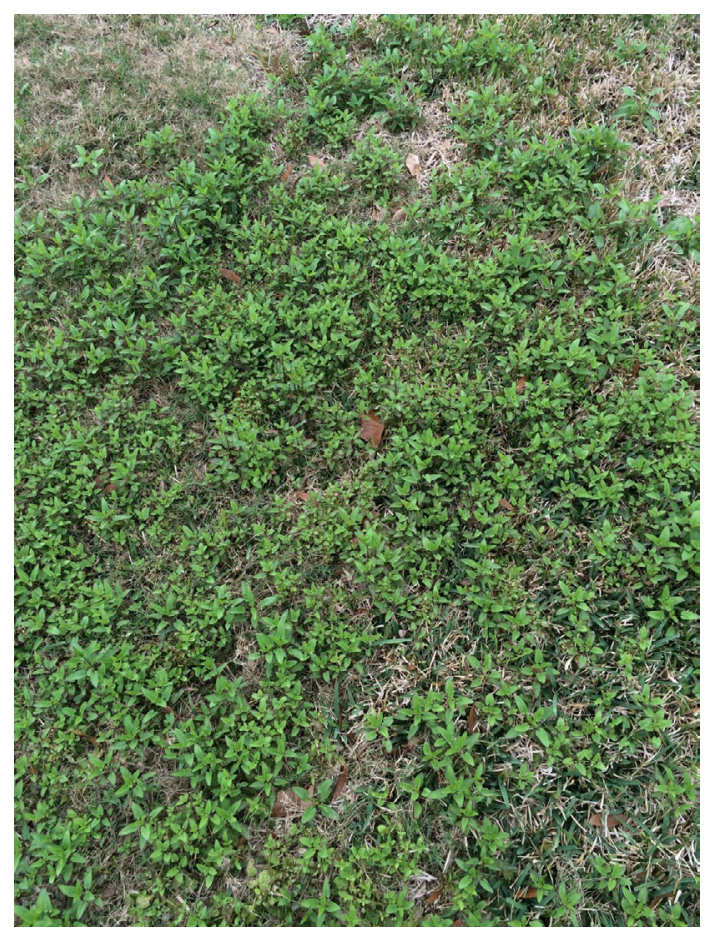

Figure 6. Florida betony can continue to spread via rhizomes even if it never develops flowers.

Credits: Chris Marble, UF/IFAS

\section{Management Physical and Cultural Control}

Florida betony is difficult to control with physical methods due to its numerous tubers and rhizomes. In landscape beds, coarse-textured mulch materials, such as pine bark, pine straw, or wood chips, can reduce Florida betony 
emergence if mulch is applied at depths of at least 2 to 4 inches. When weeding, care must be taken that tubers do not break off in the ground, because they will generate new plants. Similarly, small sections of broken rhizomes can easily sprout into new plants. For these reasons, hoeing is typically not an effective method. Hand-pulling can be successful in smaller areas, but it is important to dig down deeper into the soil and remove all rhizomes and tubers. Large infestations will usually require chemical control.

\section{Chemical Control}

Because Florida betony primarily spreads via tubers and rhizomes, preemergence herbicides are usually not effective. However, previous research has shown that prodiamine (Barricade $^{\circledast}$ ) and metolachlor (Pennant Magnum ${ }^{\circledast}$ ) can provide suppression and reduce Florida betony growth (Norcini et al. 1995; Stamps 1992). In many cases, postemergence herbicides will be needed. Postemergence herbicides, such as diquat (Reward), pelargonic acid (Scythe), and glufosinate (Finale), will burn down existing plants, but they typically do not provide long-term control because they are contact-action herbicides that are not translocated, and Florida betony can quickly regrow from rhizomes and tubers. Due to the extensive rooting structures, systemic herbicides such as glyphosate are typically recommended, but care should be taken to avoid making any inadvertent contact with nearby ornamentals.

\section{References}

Burgess, C., and J. Williamson. 2019. Florida Betony. HGIC 2313. Home and Garden Information Center. Clemson University College of Agriculture, Forestry, and Life Sciences. Accessed 17 April 2020. https://hgic.clemson.edu/ factsheet/florida-betony/

Czarnota, M., and T. Murphy. 2012. Controlling Florida Betony in the Landscape. Circular 867-11. Weed Wizard. The University of Georgia Cooperative Extension. Accessed 17 April 2020. https://extension.uga.edu/publications/ detail.html?number=C867-11

Datiles, M., and P. Acevedo-Rodriguez. 2019. "Stachys arvensis (Staggerweed)." CAB International. Accessed 16 June 2020. https://www.cabi.org/isc/datasheet/51330

Norcini, J., J. Aldrich, and M. McDowell. 1995. "Control of Florida Betony (Stachys floridana Shuttlew.) Emerging from Tubers." Journal of Environmental Horticulture 13:89-91.
Stamps, Robert. 1992. "Prodiamine Controlled Florida Betony (Stachys floridana) in Leather Fern (Rumohra adiantiformis)." Weed Technology 6:961-967.

Unruh, J., R. Leon, and D. Telenko. 2016. Florida Betony Biology and Management in Turf. ENH1127. Gainesville: University of Florida Institute of Food and Agricultural Sciences. https://edis.ifas.ufl.edu/ep388

USDA, NRCS. 2020. The PLANTS Database. Accessed 20 March 2020. http://plants.usda.gov

Wunderlin, R. P., B. F. Hansen, A. R. Franck, and F. B. Essig. 2020. Atlas of Florida Plants. Accessed 17 June 2020. http:// florida.plantatlas.usf.edu/ 